F. Reprod. Fert. (1970) 22, 199-204

\title{
RELATION BETWEEN FERTILIZATION RATE AND PENETRATION OF EGGS BY SUPPLEMENTARY SPERMATOZOA IN DIFFERENT MOUSE STRAINS AND CROSSES
}

\author{
HALINA KRZANOWSKA \\ Department of Animal Genetics, Fagiellonian University, \\ Krupnicza 50, Krakóre, Poland
}

(Received 7th May 1969)

\begin{abstract}
Summary. The percentage of unfertilized eggs, and of fertilized eggs containing supplementary spermatozoa under the zona pellucida, was estimated on the day after copulation in the diallele crosses involving inbred strains: CBA, C57, KE and one outbred strain. A significant correlation between the two investigated characters was found $(r=$ $0.84)$. The significant influence of the strain both of the male and of the female was found by the heterogeneity test. CBA, outbred, C57 and KE males yielded $0,3,5$ and $15 \%$ of unfertilized ova, and $14,18,27$ and $35 \%$ of ova containing supplementary spermatozoa, respectively. CBA females showed the lowest figures for both characters, and KE and outbred ones the highest.

The evidence seems to suggest that penetration of the vitellus is affected in KE mice because of some failure to interact on the part of both the spermatozoa and the ova belonging to this strain.
\end{abstract}

\section{INTRODUCTION}

Studies on the lower fertility of inbred strains of mice revealed that in one of them, KE, developed in this laboratory, fertilization rate is affected. In fertile matings of this strain, more than $20 \%$ of unfertilized ova may be found, half of which contain one or more spermatozoa within the perivitelline space (Krzanowska, 1960). Moreover, KE semen needs more time to accomplish fertilization, sperm entry into the vitellus being especially affected, though penetration of the zona pellucida is not delayed (Krzanowska, 1964). The process of sperm capacitation does not seem to be connected with this effect (Krzanowska, 1966).

As KE semen contains many morphologically abnormal spermatozoa (Krzanowska, 1962), the suggestion was made that perhaps some apparently normal spermatozoa may be functionally inefficient and unable to enter the vitellus. In such a case, the egg has to wait longer for the arrival of the fertilizing spermatozoon and the spermatozoon which finally enters the vitellus may not be the first to penetrate the zona pellucida. Consequently, a higher number of 
'supplementary spermatozoa', a term adopted by Austin \& Walton (1960), should be found in the perivitelline space of the fertilized eggs.

The present experiments were designed to test the validity of these speculations by comparing the fertilization rate and the number of supplementary spermatozoa in some inbred strains of mice which differ in sperm quality. As both eggs and spermatozoa are known to be responsible for the abnormalities involved in the process of fertilization (Braden, 1957, 1958), it was decided to test inbred strains not only in pure matings, but also in the diallele crosses.

\section{MATERIAL AND METHODS}

The experiments were performed on mice belonging to an outbred strain and on mice of the following four inbred strains: G57 BL (introduced from Edinburgh to Cracow in 1956 and bred in this Department since 1967), KE (Krzanowska, 1965), GBA/Kw and YS/ChWf/Kw. The following abbreviations will be used throughout the paper: outbred, C57, KE, CBA, YS. When denoting crosses, the female strain is always written first. Pure matings and diallele crosses were made between the four first-mentioned strains, while YS mice were tested only in the pure matings and in the reciprocal crosses involving the KE strain. The same males, five to seven from each strain, were used for the matings with the females belonging to different strains. As it has been noted that frequent copulation causes a drop in the fertilization rate of male mice (Krzanowska, 1968; Kaleta, 1970), males have never been used more frequently than at 3-day intervals.

On the day after a copulation plug was found, the females were killed and their Fallopian tubes flushed with $0.9 \% \mathrm{NaCl}$. Ova were mounted in a drop of the same fluid between a slide and a coverslip supported on vaseline. All eggs were inspected under the microscope for the presence of spermatozoa in the perivitelline space. Eggs at the two, or more, blastomere stage, with clearly visible nuclei, were considered to be fertilized. Undivided ova were fixed in acetic alcohol (three parts of absolute alcohol and one part of glacial acetic acid) and stained with toluidine blue to examine the chromatin structure and to decide whether they were fertilized. A few fragmenting eggs without nuclei, of an 'old' appearance, were not taken into account as they were probably derived from an earlier ovulation.

Five to nine females were examined in each mating combination till at least fifty eggs were collected, except in the $\mathrm{YS} \times \mathrm{KE}$ group where only thirty-two ova were available. Two completely sterile matings (one outbred $\times$ C57 and one $\mathrm{C} 57 \times \mathrm{KE}$ ) were not included in Table 1 and omitted from further calculations.

Information about sperm quality in the strains used was obtained from the other experiments run in this laboratory. The following mean percentages of abnormal spermatozoa were found: outbred 4\% (Krzanowska, 1962), CBA 6\%, KE 17\% (Krzanowska, 1969), C57 21\% (Brozek, 1970), YS 5\% (Kaleta, 1970).

\section{RESULTS}

The numbers of unfertilized eggs and of fertilized eggs penetrated by more than 


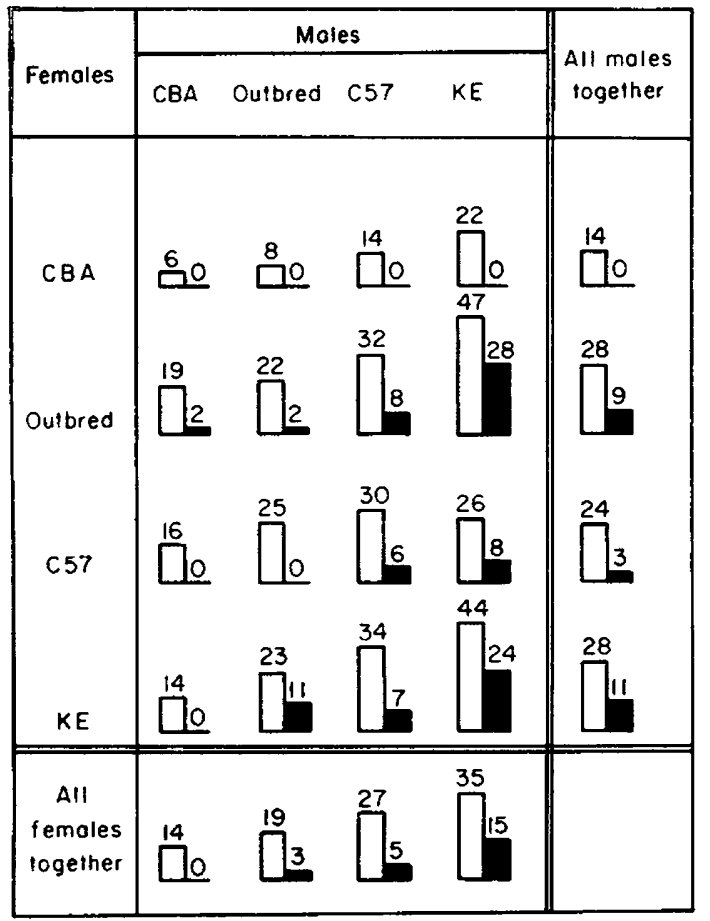

Text-Fig. 1. Percentage of unfertilized ova (black columns) and of fertilized ova containing supplementary spermatozoa under the zona pellucida (white columns) in diallele crosses involving four strains of mice.

TABLE 1

THE INCIDENGE OF UNFERTILIZED OVA, AND OF FERTILIZED OVA CONTAINING SUPPLEMENTARY SPERMATOZOA, IN DIALLELE GROSSES INVOLVING DIFFERENT STRAINS OF MICE

\begin{tabular}{|c|c|c|c|c|c|c|}
\hline \multirow{2}{*}{$\begin{array}{l}\text { Female } \\
\text { strain }\end{array}$} & \multicolumn{5}{|c|}{ Male strain } & \multirow{2}{*}{$\begin{array}{c}\text { All males } \\
\text { together (not } \\
\text { including } Y S \text { ) }\end{array}$} \\
\hline & $C B A$ & Outbred & $C 57$ & $K E$ & $r s$ & \\
\hline CBA & $\begin{array}{c}0: 3: 49^{*} \\
(1)\end{array}$ & $\begin{array}{c}0: 4: 47 \\
(1)\end{array}$ & $\begin{array}{r}0: 7: 43 \\
(1 \text { to } 2)\end{array}$ & $\begin{array}{c}0: 14: 39 \\
(1 \text { to } 2)\end{array}$ & & $0: 28: 178$ \\
\hline Outbred & $\begin{array}{l}1: 11: 46 \\
(1 \text { to } 2)\end{array}$ & $\begin{array}{c}1: 11: 40 \\
(1 \text { to } 2)\end{array}$ & $\begin{array}{c}4: 15: 32 \\
\quad(1 \text { to } 3)\end{array}$ & $\begin{array}{c}14: 17: 19 \\
(1 \text { to } 4)\end{array}$ & & $20: 54: 137$ \\
\hline C57 & $\begin{array}{r}0: 8: 42 \\
(1 \text { to } 2)\end{array}$ & $\begin{array}{c}0: 13: 38 \\
\quad(1 \text { to } 2)\end{array}$ & $\begin{array}{c}3: 14: 33 \\
(1 \text { to } 2)\end{array}$ & $\begin{array}{l}4: 12: 34 \\
\quad(1 \text { to } 3)\end{array}$ & & $7: 47: 147$ \\
\hline $\begin{array}{l}\text { KE } \\
\text { YS }\end{array}$ & $\begin{array}{r}0: 8: 50 \\
\quad(1 \text { to } 2)\end{array}$ & $\begin{array}{l}6: 11: 36 \\
\quad(1 \text { to } 2)\end{array}$ & $\begin{array}{l}4: 18: 35 \\
\quad(1 \text { to } 3)\end{array}$ & $\begin{array}{c}14: 20: 25 \\
(1 \text { to } 4) \\
\mathrm{I}: 7: 24 \\
(1)\end{array}$ & $\begin{array}{c}2: 8: 42 \\
(1) \\
0: 12: 42 \\
(1 \text { to } 2)\end{array}$ & $24: 57: 146$ \\
\hline $\begin{array}{l}\text { All females } \\
\text { together (not } \\
\text { including YS) }\end{array}$ & $1: 30: 187$ & $7: 39: 161$ & $11: 54: 143$ & $32: 63: 117$ & & $51: 186: 608$ \\
\hline
\end{tabular}

* Number of unfertilized ova : number of fertilized ova with supplementary spermatozoa : number of fertilized ova without spermatozoa in the perivitelline space.

Range of supplementary spermatozoa contained in one egg is shown in parentheses. 
one spermatozoon in the different mating combinations are shown in Table 1. Text-figure 1 gives the graphical presentation of these values expressed in percentages; the matings involving the YS strain are not included. The data are arranged in the order of increasing percentages of unfertilized eggs found in the pure matings. It may be seen that the proportion of fertilized eggs containing supplementary spermatozoa follows the same order. The correlation between the two characters amounts to $\mathrm{r}=0.87$ (d.f. $=3 ; P=0.06$ ) when pure matings only are considered, and to $\mathrm{r}=0.84$ (d.f. $=17 ; P<0.0001$ ) when crosses are also taken into account.

Both the male and female strains are important in the performance of crosses, as was shown by the $\mathrm{R} \times 2$ heterogeneity test done by the Brandt and Snedecor method (Snedecor, 1955). When the eggs of all females together were taken into account, the heterogeneity due to the source of the male was significant $\left(\chi^{2}=28 \cdot 10 ;\right.$ d.f. $\left.=3 ; P<0 \cdot 0001\right)$. Heterogeneity due to the source of the female for all males together, was also significant $\left(\chi^{2}=16 \cdot 18\right.$; d.f. $\left.=3 ; P<0.001\right)$. $\mathrm{KE}$ males consistently yielded the highest figures. This occurred whether the eggs from all females together were considered (bottom row of Text-fig. 1) or those from each strain separately. CBA males which had fertilized practically all available ova had the lowest figures and supplementary spermatozoa were not found in more than $20 \%$ of fertilized eggs.

A similar situation is found when the female strain is taken into account. Again, the lowest figures were obtained in the matings involving CBA females, irrespective of the strain of the male used in the cross. All available ova of CBA females were fertilized, even in the matings with the KE males; the maximal proportion of eggs penetrated by more than one spermatozoon amounted to $22 \%$. The highest figures belong this time, however, not only to KE females but to outbred ones, as well.

Thus, as far as the male strain is concerned, the order of increasing proportion of unfertilized eggs, and of fertilized eggs penetrated by more than one spermatozoon, arranged on the ground of pure matings $(\mathrm{CBA}<$ outbred $<\mathrm{C} 57<\mathrm{KE}$ ), is also followed in the cross-matings. The analogous order arranged for the females is somewhat different, namely: $\mathrm{CBA}<\mathrm{C} 57<\mathrm{KE}=$ outbred. $\mathrm{CBA}$ and $\mathrm{KE}$ strains lie at the two extremes, as far as both males and females are concerned.

It should be noted that in all types of matings, if any unfertilized eggs were found, about half of them always contained at least one spermatozoon in the perivitelline space (the maximal number of spermatozoa found this time in the KE-strain egg was six). The range of the numbers of supplementary spermatozoa found in the fertilized eggs is indicated in Table 1. These numbers tend to correlate with the proportion of ova penetrated by more than one spermatozoon. No polyspermic ova were noticed in the present investigations.

\section{DISCUSSION}

The eggs of two strains of mice, CBA and C57, used in the present experiments and examined for supplementary spermatozoa by Braden (1958), yielded an incidence of $10.8 \%$ for $\mathrm{CBA} \times \mathrm{CBA}$ and $27.9 \%$ for $\mathrm{C} 57 \times \mathrm{C} 57$ matings; these 
figures are very similar to those presented in this paper. Such a finding indicates strong genetical control of this character, which is firmly inherent in the genetical constitution of the strain and did not change in spite of the long time distance (11 years) separating both investigations.

On the grounds of his very thorough experiments involving five inbred strains in the different mating combinations, as well as backcrosses, and of having examined many other characters connected with fertilization, Braden (1958) came to the conclusion that the genotype of the male largely determines the proportion of eggs that are penetrated by more than one spermatozoon: in one instance, there was evidence that the strain of the female also had a significant effect. He discussed two possible explanations for the higher incidence of supplementary spermatozoa in eggs fertilized by C57 spermatozoa. Firstly, it may reflect a higher sperm-egg interception rate as a consequence of either a greater motility of the C57 spermatozoa or their larger number at the site of fertilization. Secondly, it may be explained in terms of the reactions of either gamete after the spermatozoon has penetrated the zona pellucida. If the reaction of the vitellus is slower, or the delay between the penetration of the zona and the attachment of the sperm head to the vitelline surface longer, then the zona reaction begins later or needs more time to reach completion with the result that a larger proportion of eggs is penetrated by an extra spermatozoon. Braden (1958) found some evidence that a higher motility of C57 spermatozoa may be involved in the difference between CBA and C57 strains.

The evidence presented here, and especially the correlation between the proportion of unfertilized ova (half of them with a penetrated zona) and those containing supplementary spermatozoa, seems to indicate that the penetration of the egg by more than one spermatozoon may also be connected with some inability of spermatozoa from certain strains to enter the vitellus. The highest incidence of supplementary spermatozoa in the eggs was found in the matings involving the strains with the highest percentage of morphologically abnormal spermatozoa: $\mathrm{KE}$ and $\mathrm{G} 57,17$ and $21 \%$, respectively, while the lowest incidence involved the CBA strain with only $6 \%$ of abnormal spermatozoa. Although it is believed that the high content of morphologically abnormal spermatozoa should not be regarded as the cause of sterility, or semi-sterility, nevertheless it may serve as an indication (Bryson, 1944).

The conclusion reached by Braden (1958) that the male strain is important in establishing the proportion of the ova penetrated by more than one spermatozoon is confirmed in the present experiments, but the importance of the female strain is more clearly evident now than in his experiments. It seems probable that the second of the factors mentioned by Braden, namely the difference in the reaction between the egg and the spermatozoon, may be involved here.

The present experiments show that in two cases (CBA and KE), the strain of the egg and of the spermatozoon tend to shift the proportion of supplementary spermatozoa at fertilization in the same direction. This may not be mere coincidence. It has been suggested that the acrosome of the spermatozoon and the cortical granules of the egg, structures involved in the process of sperm entry into the ovum, may both be derived from the Golgi apparatus (Szollosi, 
1967). It is, thus, not unreasonable to think that the same genes which influence some abnormality of sperm function may also be involved in anomalies of the cortical granules, their number or reaction. Further experiments are needed to elucidate this point. It has already been noted that both autosomal or X-linked and $\mathrm{Y}$-linked genes are involved in the difference in sperm quality between $\mathrm{KE}$ and CBA strains (Krzanowska, 1969).

Finally, it should be emphasized that the causes of the higher incidence of supplementary spermatozoa may not be the same in different strains. Depending on the genes that happen to be fixed in each strain, the same end result may be attained in a different way. This applies to all polygenic characters and has already been cited in relation to the component factors affecting litter size in inbred strains of mice (Krzanowska, 1967).

\section{REFERENCES}

Austin, G R. \& Walton, A. (1960) Fertilization. In: Marshall's Physiology of Reproduction, Vol. 1, part 2, chap. 10. Ed. A. S. Parkes. Longmans, Green, London.

BRADEN, A. W. H. (1957) Variation between strains in the incidence of various abnormalities of egg maturation and fertilization in the mouse. F. Genet. 55, 476 .

Braden, A. W. H. (1958) Variation between strains of mice in phenomena associated with sperm penetration and fertilization. $\mathcal{F}$. Genet. 56, 37.

BRożeK, C. (1970) Proportion of morphologically abnormal spermatozoa in two inbred strains of mice, their reciprocal $F_{1}$ and $F_{2}$ crosses and the backcrosses. Acta biol. cracov., Sér. Zool. 13, (in press).

BRYsON, V. (1944) Spermatogenesis and fertility in Mus musculus as affected by factors at the T-locus. 7. Morph. 74, 131 .

KALETA, E. (1970) Reproductive performance of yellow $\left(A^{y_{a}}\right)$ and nonyellow (aa) inbred and $F_{1}$ hybrid mice. Acta biol. cracov., Sér. Zool. 13, (in press).

KrzanowsKa, H. (1960) Studies on heterosis. II. Fertilization rate in inbred lines of mice and their crosses. Folia biol., Kraków, 8, 269.

KrzanowsKa, H. (1962) Sperm quality and quantity in inbred lines of mice and their crosses. Acta biol. cracov., Sér. Zool. 5, 279.

KrzanowsKa, H. (1964) Time interval between copulation and fertilization in inbred lines of mice and their crosses. Folia biol., Kraków, 12, 231.

Krzanowska, H. (1965) New inbred strains of mice. Mouse News Lett. 32, 54.

KrzanowsKa, H. (1966) Fertilization rate in mice after artificial insemination with epididymal or "capacitated" sperm from inbred and crossbred males. Folia biol., Kraków, 14, 171.

KRZANowsKa, H. (1967) Analysis of fertility factors in inbred mice and $F_{1}$ hybrids. Genet. pol. 8, 231.

KRZANOWSKA, H. (1968) The effect of frequency of mating on the sexual activity and fertilizing capacity of inbred and $\mathrm{F}_{1}$ hybrid male mice. (In Polish with English summary.) Zwierzegta Laboratoryjne. $6,7$.

KRZANowsKa, H. (1969) Factor responsible for spermatozoan abnormality located on the $Y$ chromosome in mice. Genet. Res. 13, 17.

SNedecor, G. W. (1955) Statistical methods. Iowa State College Press, Ames, Iowa.

Szollosi, D. (1967) Development of cortical granules and the cortical reaction in rat and hamster eggs. Anat. Rec. 159, 431. 